\title{
Increased Competitiveness of Leading Products Based on Bengkulu Robusta Coffee
}

\author{
Afif Abdulquddus ${ }^{1}$, Hartrisari Hardjomidjojo ${ }^{2}$, Indah Yuliasih ${ }^{3}$ \\ \{afifabdulquddus@yahoo.com ${ }^{1}$, sari@biotrop.net ${ }^{2}$, indahyul1870@gmail.com $^{3}$ \} \\ College Student In Agricultural Industrial Engineering Study Program, IPB University (Bogor \\ Agricultural University $)^{1}$, Lecturer In Agriculture Industry Engineering Study Program, IPB University \\ (Bogor Agricultural University) ${ }^{2}$, Lecturer In Agriculture Industry Engineering Study Program, IPB \\ University (Bogor Agricultural University) ${ }^{3}$
}

\begin{abstract}
Bengkulu Province is the third largest robusta coffee producer in Indonesia. Its potential has good physical qualities of seeds, has distinctive taste and aroma, strong character, and has Geographical Indications (IG). So the opportunity to turn Bengkulu Robusta coffee into a superior product is huge. The goal to be achieved is to improve the competitiveness of Robusta Bengkulu-based superior products. The method used is a literature study to prove that Bengkulu coffee has the potential to be a superior product, for the selection of superior products and the selection of processes using expert interviews, to test the level of panelist satisfaction using a Likert scale. The results obtained by Bengkulu coffee can be a regional superior product and the selected superior products are ground coffee with dry processing, medium roasting process, and fine milling. The production process is workable and the product is favored by panelists.
\end{abstract}

Keywords: increasing competitiveness, featured product, Bengkulu robusta coffee. 


\section{Introduction}

Bengkulu Province is the largest robusta coffee production center in Indonesia after South Sumatra and Lampung [1]. These three provinces have the highest number of production produced from South Sumatra, 110.481 tons, Lampung 110.325 tons and Bengkulu 55.150 tons [1]. The most robusta coffee producing areas in Bengkulu Province are Kepahiang District (18.300 tons) and Rejang Lebong District (13.421 tons), Robusta coffee production in Bengkulu of more than $50 \%$ is produced from the two districts [1]. Bengkulu coffee plantations are dominated by smallholders with a total area of 95.016 ha or $99,17 \%$, while private plantations are 784 ha or $0,83 \%$ [2].

The regency is located in the Bukit Barisan mountainous plateau region, which is mostly at an altitude of between 500-1000 meters above sea level (m asl) and high rainfall between 2.504-3.768 $\mathrm{mm} /$ year with an average of 313 $\mathrm{mm} / \mathrm{month}$ [3]. Soil types in the district generally consist of: Andosols, Regosols, Podsolic, Latasol and Alluvial with medium soil texture, loam and slightly sandy and soil $\mathrm{pH}$ 4.5-7.5 [3]. Generally Robusta coffee grows in the lowlands at an altitude of $500 \mathrm{~m}$ [4], but Bengkulu Robusta coffee can grow well in the highlands. [5] has conducted a study of the effect of altitude on the robusta coffee favorite level test in Bengkulu, the results obtained by robusta coffee grown in the highlands produce a preference level test with a score $>80$ which means Bengkulu robusta coffee is preferred by panelists.

The potential of Bengkulu Robusta coffee is that it has good physical quality of beans, has distinctive flavor and aroma (dark chocolate, caramely, flowery and woody), strong character (high body \& long after taste) and has the highest taste test results with a score of 85,25 which can be classified in the scale of excellent flavors and meet special coffee qualifications with a value $>80$ [5]. Bengkulu Robusta Coffee has received a Geographical Indication (IG) from the Ministry of Law and Human Rights (Kemenkumham) located in Kepahiang Regency in 2018 [3] and Rejang Lebong Regency in 2019 [6]. The opportunity to make Bengkulu Robusta coffee into a superior product is very large and to add Robusta specialty products in Indonesia that previously existed such as: Java Dampit Robusta, Bali Pupuan Robusta, Lampung Robusta and Flores Robusta [7]. 
[8] said the main problems faced in coffee in Bengkulu were low productivity, low product quality and low selling prices at the farm level that caused Bengkulu Robusta coffee could not compete with other types of coffee. When compared with Lampung coffee the average production reaches 140.983 tons, while for Bengkulu it reaches an average production of 63.821 tons. [9] revealed the Bengkulu coffee marketing trade chain as a coffee exporter in Lampung and Palembang.

One strategy that can be done to empower Micro, Small and Medium Enterprises (MSMEs) is the One Village One Product (OVOP) program. OVOP is a community movement by involving the government to move the typical products of the creativity of local communities in the area from the village level to the district or city level [10]. The one-product village (OVOP) movement was first introduced by Japan to improve the economy of rural communities in Japan. Some countries that have successfully followed Japan's OVOP approach are Thailand (One Tambon One Product), Taiwan (One Town One Product), Malaysia (One District One Industry), Philippines (One Town One Product) and Cambodia (One Village One Product) [11]. Bengkulu Robusta coffee can become a regional superior product by taking an OVOP approach to increase regional income and have high product competitiveness.

Bengkulu robusta coffee which already has a geographical indication (IG) is expected to compete in the global market and be protected from counterfeiting of products by irresponsible parties [3] as well as increasing product value added and getting recognition for the quality and peculiarity of Bengkulu robusta coffee products [6]. The types of coffee that get the geographical indication label are Coffee Rice (Green Bean), Roasted Coffee (Roasted Coffee) and Ground Coffee. Coffee products in Indonesia have amounted to 31 coffee products that have obtained geographical indications including: 17 arabica coffee, 12 robusta coffee and 2 liberika coffee [7]. However, the formulation of the problem in this research is that it is necessary to prove that the robusta bengkulu coffee has the potential to be a regional superior product, it is not yet known what coffee products can be superior, it is not yet known what process, what kind of production process and what kind of test results of the level of preference for panelists. which can improve the regional economy and be highly competitive. 
The purpose of this study was to improve the competitiveness of superior products based on Robusta coffee bengkulu. To increase the competitiveness of Bengkulu Robusta coffee, it is necessary to diversify products or new products that can be seen from the coffee industry tree (Appendix 1) that can be developed in Bengkulu adjusted to human resources (HR) and technology in Bengkulu. So that it hopes that what products will be superior in Bengkulu coffee will emerge and the impact will be given to improve the economy of Bengkulu region and highly competitive.

\section{Method}

\subsection{Framework}

The research framework in this study starts from a literature study to prove that the robusta bengkulu coffee has proven potential to be a superior product, then determines the superior product seen from the coffee industry tree with indepth interviews with 3 coffee experts, then determines the chosen process by interviewing 3 coffee experts, Furthermore, after the products and processes have been selected, the production process will be carried out and their favorite level tested directly to 30 coffee drinker panelists using a Likert scale (5 scale) and the results will be seen whether the superior product is liked and has competitiveness. The framework of the researcher can be seen as follows: 


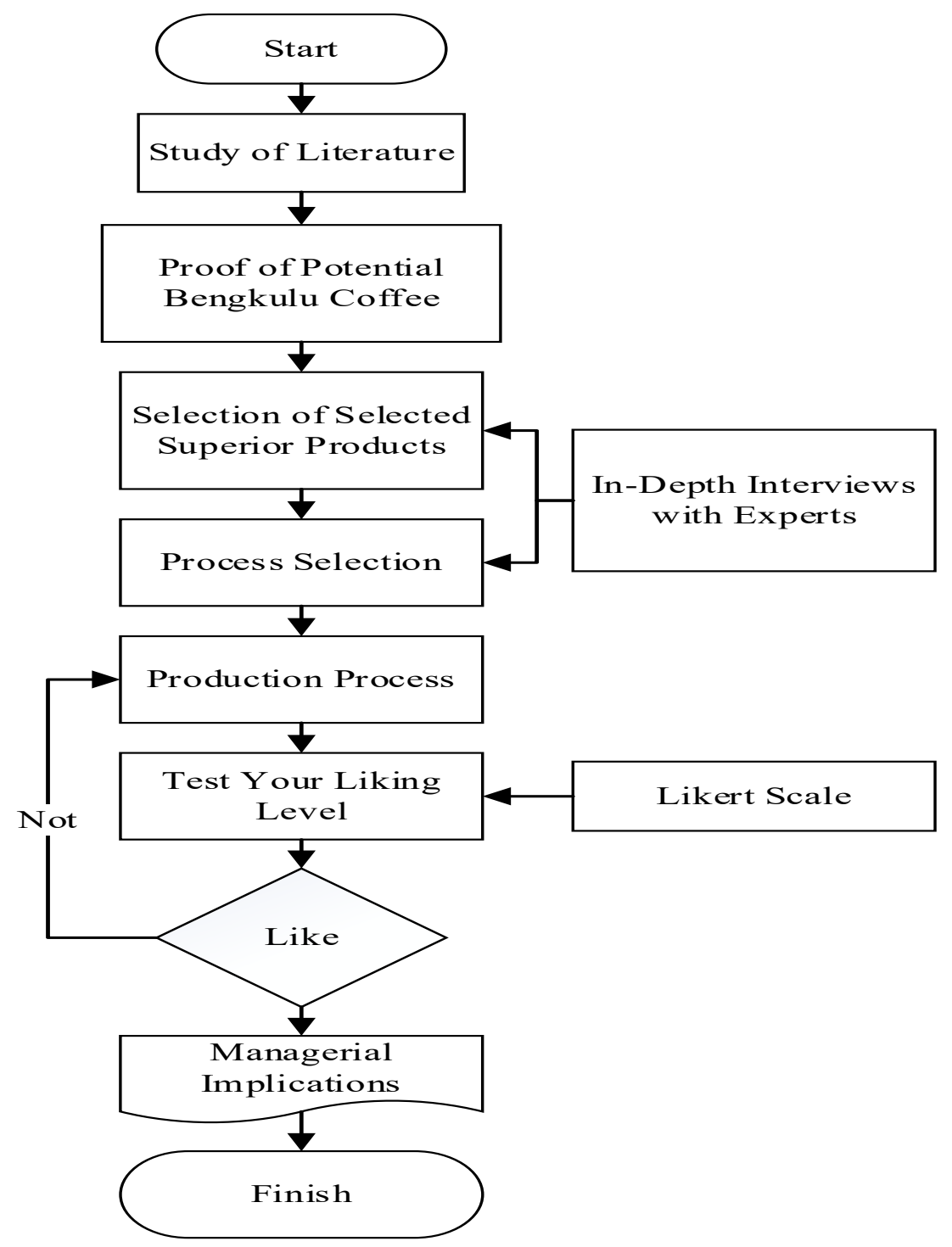

Fig. 1. Framework. 


\subsection{Research Stages}

As for the stages of research researchers as follows:

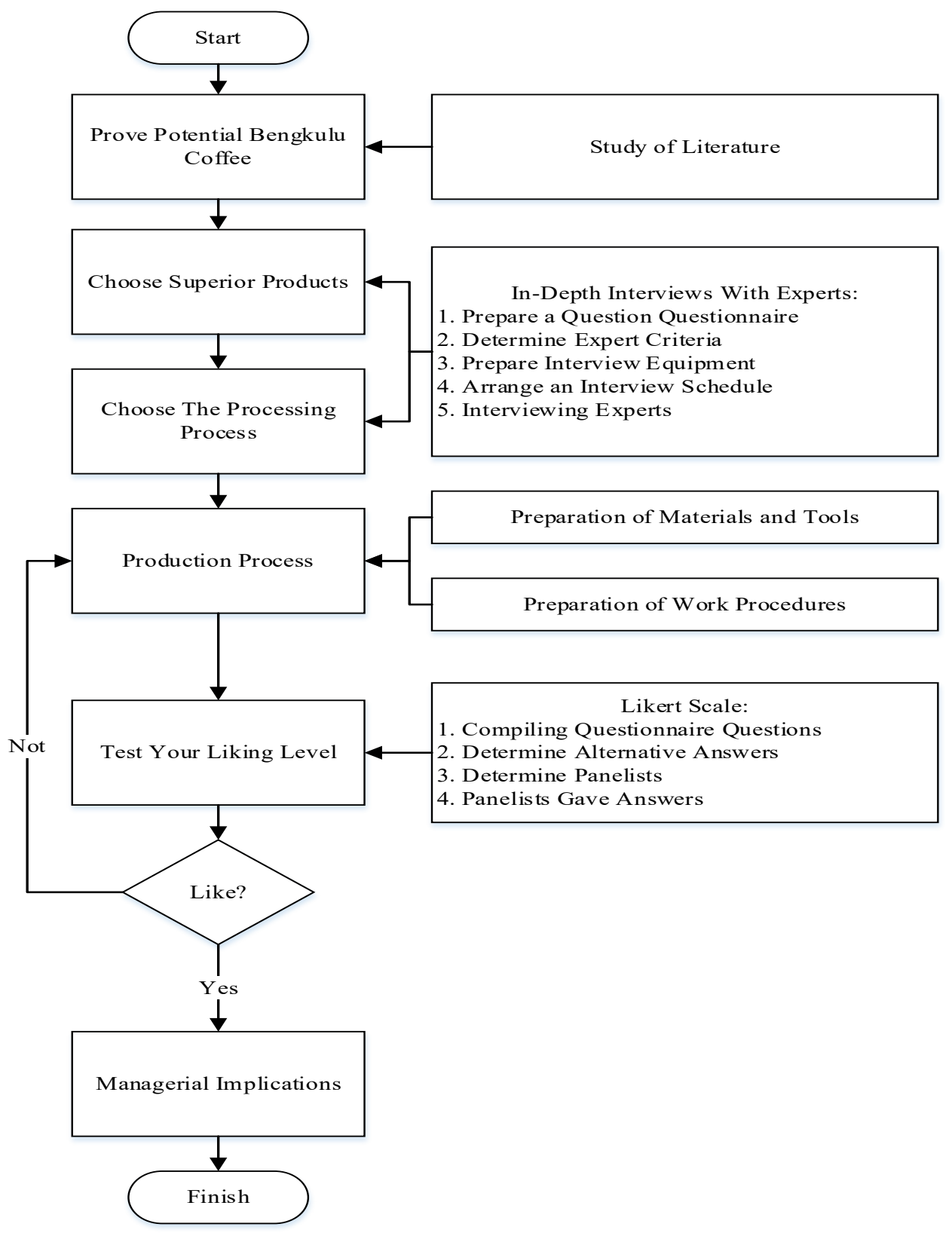

Fig. 2. Research Stages. 


\subsection{Research Location and Research Time}

This research will be conducted in two regencies of Bengkulu Province, namely Kepahiang Regency and Rejang Lebong Regency which are the largest Robusta coffee producers in Bengkulu. The time of the study will start from March to May 2020.

\subsection{Tools and Materials}

The tools and materials used in this study are as follows: tools (dryers, hullers, containers, ovens, grinders, scales, cups, spoons, water heaters, pens), ingredients (robusta coffee fruit, water, packaging, questionnaire paper).

\subsection{Method of Collecting Data}

Data collection uses purposive sampling technique with in-depth interviews with stakeholders such as: three coffee expert and four Robusta coffee MSMEs in Kepahiang and Rejang Lebong Districts. The data to be obtained in this study are primary data and secondary data. Primary data in the form of data obtained from respondents through questionnaires (Appendix 2), panelists and the results of interviews with coffee experts. While secondary data in the form of data obtained from literature studies.

\subsection{Proof of Potential Bengkulu Coffee}

This stage is the beginning to prove that Bengkulu coffee is potential and can be a superior product. The method used is a literature study collecting data on the potential of Bengkulu coffee and its superiority. Having found that Bengkulu coffee has potential and can be a superior product, then it will proceed to the next stage, namely the selection of superior products, the selection of processes, the production process and the level of preference for panelists.

\subsection{Product Selection}

The in-depth interview process was conducted question and answer face-toface or online between researchers and predetermined coffee experts. The criteria for coffee experts needed in this study is to have knowledge of coffee products and experience in coffee at least one year. Coffee experts needed in this study were three experts. In this study, researchers asked coffee experts to choose what coffee products were the most potential and could become superior products in Bengkulu that can be seen from the coffee industry tree (Appendix 1) and also the reasons for the coffee experts why to choose such superior products. 


\subsection{Process Selection}

The selection of this process is the next stage after which superior coffee products have been selected. The criteria for coffee experts needed in this study is to have knowledge about the processing of coffee from upstream to downstream, having experience in coffee at least one year. The selection process is done by asking coffee experts about the process to be selected and the reason why choosing the process.

\subsection{Production Process}

The production process will be carried out after the product is selected and the selected process results in-depth interviews with coffee experts. Then prepare materials and tools, work procedures to make these superior products. Then the product will be tested on their favorite level by panelists.

\subsection{Favorability Test}

This test is conducted to determine the level of preference for a product to be accepted by panelists. The testing method used in this study is to use a Likert scale. Panelists were asked to respond to superior products. Likert scale provides 5 alternative answers, namely Very Like (SS), Like (S), Enough Like (CS), Less Like (KS) and Dislike (TS) [12]. Panelists in this study will be determined after the superior product is known in advance to avoid bias. Rating of each criterion can be calculated as follows:

Information :

$$
\mathrm{RK}=(\mathrm{m}-\mathrm{n}) / \mathrm{K}
$$

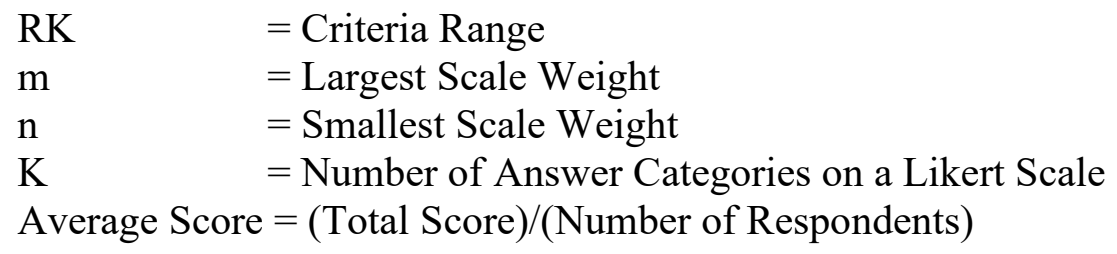

\subsection{Data Analysis Method}

The analysis used in this research is descriptive analysis. To prove that Bengkulu coffee has the potential to use literature studies, to determine what coffee products are Bengkulu superior from the results of in-depth interviews with coffee experts. Then the selection of Bengkulu superior coffee processing products will be conducted from in-depth interviews to coffee experts. Furthermore, selected superior products are produced and tested the panelists' preference level using a Likert scale. 


\section{Results and Discussion}

\subsection{Proof of Potential Bengkulu Coffee}

Bengkulu Robusta coffee-producing areas are scattered in several parts of the district/city, namely: North Bengkulu, Mukomuko, Rejang Lebong, Kepahiang, Lebong, South Bengkulu, Seluma, Kaur, Bengkulu and Bengkulu Tengah [1]. Robusta coffee grows well in the lowlands to an altitude of $1000 \mathrm{~m}$ above sea level and Robusta coffee is more resistant to leaf rust, whereas for Arabica coffee it can only grow in the highlands and for liberika coffee only in the lowlands [14]. So the superiority of this robusta coffee can grow at various levels in the lowlands and highlands and robusta coffee still dominates its production in Indonesia by $83 \%$ compared to Arabica coffee by $17 \%$, but the international market prefers Arabica coffee [1].

Bengkulu coffee plantations that are getting old and damaged need rejuvenation and rehabilitation processes. The results showed that Robusta Green Umbrella clone from Kepahiang had the highest stability and yield of beans compared to other superior clones in Kepahiang [15]. Payung Hijau clone coffee production reached $1,19 \mathrm{~kg}$ dry weight of seeds/tree 4,31 $\mathrm{g}$ fresh weight/fruit and 0,63 g dry weight/seed. Thus making Payung Hijau clones a potential source of entry for the rejuvenation or rehabilitation of old coffee plantations [15].

Coffee commodity is one of the leading commodities in Bengkulu apart from oil palm, rubber, cocoa and pepper plantations. Coffee plantations have long been a major source of income for farmers, especially in Kepahiang and Rejang Lebong which has the highest coffee plantations in Bengkulu. This encourages the government to more aggressively develop Bengkulu coffee [9]. One of Bengkulu coffee clones, Sidodadi, is the most developed because of the high taste test results with a score of 85,25 classified as specialty coffee (score $>80$ ) having the character of high body, long aftertaste and the aroma of dark chocolate and Caramelly [5].

The Bengkulu government is now intensively developing coffee agro tourism in Bengkulu so that Bengkulu coffee is increasingly well known both inside and outside Bengkulu, guiding the community in gardening, postharvest to barista training ranging from coffee dispensing to serving with direct consumers.

Many people who do not know Bengkulu coffee, some of the advantages possessed by Bengkulu coffee, namely: it has a variety of aromas (lemon, chocolate and distinctive herbs), the third largest production in Indonesia, often participating in the national coffee festival to rank 5th in the Research Center (PUSLIT) national coffee, had won the Indonesian special contest at the 2016 
Indonesian Special Contest (KSI) or Indonesia Cupping Competition held by the Association of Indonesian Coffee Exporters and Industries (AEKI) together with the Indonesian Coffee and Cocoa Research Center (PPKKI) in Jakarta which was assessed from a jury of 12 countries. Bengkulu Coffee was included in the Outstanding category in the point of sweetness, clean up, acidity, aftertaste and overall (General Chairperson of the AEKI Central Management Agency) [16].

Of the several potentials and advantages of Bengkulu Robusta coffee that has been described above is sufficient to prove that Bengkulu Robusta coffee potential can be a regional superior product. One of the requirements to be a regional superior product is: it has its own uniqueness, its production is always continuous, a source of income and is ready to compete with other similar or not similar products.

\subsection{Selection of Selected Superior Products}

The selection of this superior product was chosen based on the opinion of the three coffee experts who certainly had experience in coffee. The alternative selection of superior coffee products is seen from the coffee industry tree (Appendix 1) which will be chosen by the three coffee experts.

For the first expert, a lecturer from IPB University who has 10 years experience in coffee stated that the coffee variant or form to be selected is roasted coffee as the superior product of Bengkulu coffee. This roasted coffee must be packaged well because the aroma will quickly disappear, if not packaged properly. As a coffee person I prefer to buy coffee products in the form of roasted beans. If you buy coffee that has been ground (ground coffee), the aroma that has been obtained has a lot of loss. And also for other coffee variants such as: mix coffee and instant coffee (already added sugar normally), decaffeinated coffee (caffeine in coffee has been reduced) which causes reduced taste of coffee (single origin of Bengkulu coffee). And also in Bengkulu, existing coffee products, roasted coffee and ground coffee. For instant coffee, mix coffee, decaffeinated coffee and others there is no industry in Bengkulu, in terms of technology it is also inadequate. In terms of manpower specifically for the roaming section, only one person who already has expertise in the field, so do not need a lot of labor. Whereas farmers usually only process coffee beans into coffee beans only. For the waste itself, from the waste of horn skin and epidermis can be made of ulin, charcoal, acetic acid and others, while for leather and fruit waste waste can be made of silage, pectate enzymes, ethanol and others. Usually the most waste produced in the coffee processing is washing. So the water treatment process needs to be done so that wastewater does not have a major impact on the environment. Suggestions that can be given try to also 
think about to see the export share of outside coffee and try to export to the outside. In Bengkulu itself, exports have not been carried out because they still cannot follow the regulations that are applied so that the role of the government is very important here must encourage coffee in Bengkulu to be more developed and advanced and can export abroad which can increase the income of local farmers.

For the second expert, a Barista Leader at Centrum Coffee who has 5 years of experience in the field of coffee mentioned that for today the term roasted is called roasting. Coffee roasting is the process of cooking coffee beans. To drink coffee, roasted coffee will be milled first, then ground into ground coffee. Therefore I prefer ground coffee. If I choose roasted coffee, people who are new to coffee will ask what kind of roasted coffee. Whereas if it is ground coffee then the layman certainly understands immediately that what is meant / its form has become powder. From the technology side of the past and present there are many changes in the coffee processing. for ancient times still use pounded with stone, whereas now it uses a machine. Suggestions that can be given need to improve in terms of marketing (marketing) because marketing is very important to increase farmers' income and make Bengkulu coffee better known to many people.

For the third expert, Co Founder of a Coffee House who has 6 years experience in coffee mentioned that the selection of this superior product is based on the potential of Bengkulu coffee. In his opinion, the most potential product of Bengkulu coffee is roasted coffee. The reason for choosing roasted coffee is its good quality. However, in Bengkulu itself the processing is not good, the coffee beans that should be used are in the form of fine green (all red in color), while in Bengkulu itself most farmers still pick many that are still green or immature. Even though the resources of Bengkulu are good, the coffee bean exporters in the cafes are already good. Suggestions that can be given need to be upgraded to build a training center, starting to improve in terms of processing, then cultivation. There is no influence on the environment and it can be applied in Bengkulu. If all that can be done then Bengkulu coffee is getting better quality, more people are known and can certainly raise the name of Bengkulu coffee and increase farmers' income.

After interviewing the coffee experts above, it can be seen that there were differences of opinion between the three experts, where two experts choose roasted coffee, while one expert chose ground coffee as Bengkulu's superior product. Then, the researchers tried to survey consumers who normally drink brewed coffee to 30 consumers in Dramaga, Bogor to choose between roasted coffee or ground coffee. The survey results showed that 24 consumers chose ground coffee and 6 people chose roasted coffee. For those who choose ground 
coffee the reason is simple, practical, not complicated, instant, easy to make, does not have to be mashed, is faster, only brewed and the name of ground coffee is also common to sound so people know right away, and do not have to have a grinder. Whereas for those who choose roasted coffee the reason is the seeds are still fresh, then after grinding the aroma is still fragrant, strong, the aroma is more out, the taste of the coffee is better.

From the results of expert interviews and the results of consumer surveys conducted there are differences in results between roasted coffee and ground coffee, it can be concluded that although experts are more likely to choose a superior product, roasted coffee, but after a survey of 30 consumers who drank their brewed coffee more many choose to ground coffee because its name is commonly heard and even many still do not know how the shape of the roasted coffee itself. So the selected superior product is ground coffee for the reasons mentioned earlier.

\subsection{Process Selection}

For the selection of processes in the superior product that is ground coffee seen from the opinion of the three coffee experts who have knowledge about the process of coffee both from upstream to downstream. Where experts are asked to choose the stages of the process that is suitable for this superior product and its reasons.

For the first expert, as a Trainer and Barista at Ranin Coffee House who has 3 years experience in coffee, according to him, processing coffee beans into coffee beans is generally done in two ways namely dry (natural and honey) and wet (semi wash and full wash). Generally for robusta coffee the technique commonly used is the dry method because the process is simple and easy to apply to farmers. While the wet method is usually done for Arabica coffee which requires a slightly more expensive process. For Robusta coffee usually to get a difference from a variety of processes that the change is not significant. So I prefer the dry method (natural) because it would be more suitable for Robusta. In terms of price and the market is not much different from the others, then the taste and aroma are different for each processing but not too significant. Usually Robusta coffee is sold the most expensive among Rp. 30.000-35.000 in the form of coffee beans $/ \mathrm{kg}$. Then the roasting process I prefer to medium because Robusta is more suitable with a slightly dark and mature color and also the direction is more towards the brewing coffee brewing method if the type of coffee is Robusta. In terms of price and market there is also no difference but it is more influential to the change in color. For the milling process, I prefer Fine because it is suitable for brewed coffee using sugar. For the selection of grinding depends on the purpose we want to use the brewing method. In terms of price 
and market, there is no difference and the taste and aroma are not too different. The only difference is the size.

For the second expert, a lecturer at TIN IPB University who has 5 years experience in coffee, according to him, processing coffee beans into coffee beans there are two processes namely wet and dry methods. I prefer the wet method because it will produce a stronger sour taste and usually the wet process is sold more expensive than the dry method and also the processing costs more expensive than the dry method. For the roasting process I chose medium because acidity is more dominant and caffeine content is not too high. This type of roasting has different characteristics, distinct characteristics and returns to the tastes of the consumers themselves. For the milling process I chose fine because I enjoyed the type of espresso coffee which took about 2 minutes and generally the coffee on the market was this type. Because the fine grind is usually for espresso coffee with a fine grind. From the price side there is no effect, from the market side back to the tastes of consumers. This type of mill produces different types of coffee brewing and flavors and aromas.

For the third expert, as an owner of Bengkulu Kito Coffee UKM who has 8 years experience in coffee, according to him, processing coffee beans into coffee beans is divided into four ways namely natural and honey (dry way), semi wash and full wash (way wet). In opinion prefer to choose the dry process (natural) because of the habit of Bengkulu people who used to drink collapsed coffee. In terms of prices for wet processes it will be more expensive because the costs incurred are also expensive compared to other processes. For different flavors and aromas of some of these processes. Generally natural has a taste of dark chocolate, vanilla, body, sour and durian. For roasting processes, generally Robusta Bengkulu coffee uses medium to dark and dark roast. The difference is the level of roasting, taste, temperature and roasting time. For Robusta I chose the medium roasting process. For the price, there is no difference between the tastes of consumers. For milling, I prefer a fine grinder because it is very suitable for the brewed coffee that people drink every day. For robusta brewing methods that are often used are base espresso, impact and Vietnam drip.

From the results of online interviews with three coffee experts about the selection process in processing superior products, namely ground coffee. Each expert chose a different processing process, namely to process coffee beans into coffee beans, ie two experts chose the dry method, while the other experts chose the wet method. For the roasting process of coffee beans the process chosen by the three experts is the same, medium. For the milling process chosen by the experts the same is fine milling. But experts say that the selection process depends on each customer again because they have different satisfaction. Every process has its own market. It all depends on the demand of consumers who 
want coffee with what process. So, usually we like it. And it can also be seen from the second expert who chooses coffee processing based on his chosen coffee preferences.

All choices chosen are certainly full of their respective considerations. So the process steps taken to make this superior product is the processing of coffee beans into coffee beans is the dry way because two dominant experts choose to go there and the process of drying costs is cheaper than the wet method and the process is easily done by farmers and can even be done at home. Then for the roasting process the medium is chosen because all three experts choose the same process and for roasting the medium can produce a more fragrant aroma and the color is not too dark or not too light brown and the coffee beans are ripe. Then for the selected grinding process is fine because all three experts choose the same process and for coffee, it is more suitable to use fine milling and most consumers prefer fine milling so that the coffee powder dissolves quickly in water.

\subsection{Production Process}

This production process stage is the stage after the selected superior product that is ground coffee and the selected process is a dry method for processing coffee fruit, roasting medium coffee beans and grinding fine coffee beans. The material used was Sintaro coffee from Rejang Lebong with all red quotes, drying the fruit using a greenhouse to a moisture content of $\pm 12 \%$ according to SNI for ground coffee. For the processing of coffee fruit into coffee beans, weight loss occurs up to $80 \%$ due to the separation of fruit flesh, epidermis and horn skin. For roasting process using a roasting machine from IKM Sintaro coffee from Rejang Lebong there is a reduction in weight on the seeds because the roasting process can reduce water content by $5-8 \%$ [14] and roasting process is carried out for \pm 12 minutes because of the total roasted coffee beans $\pm 1 \mathrm{~kg}$ with a temperature of $\pm 180^{\circ} \mathrm{C}$. For the grinding process using a grinding machine at the Papuk Mamuk Cafe \& Resto with fine milling. For the results obtained a fragrant aroma, fine texture and brownish color, not dark. So this production process is very easy to do or implemented in Bengkulu, especially can be done by farmers.

\subsection{Test Your Liking Level}

The preference level test for this superior product will be trialled to 30 panelists who usually drink black coffee, the product evaluation only asks whether they like it or not with this product and why. There are five alternative answers namely Very Like (SS), Like (S), Ordinary (B), Dislike (TS) and Very Dislike (STS). So superior products will be juxtaposed with 4 other same-type 
robusta coffee products whose names are already well-known in Bengkulu. The total products to be tested are 5 favorite levels with a code description: A1, A2, A3, A4 and A5. For coffee products, there are 1001 coffees, Gading Cempaka coffees, Raflesia coffees, Bsamo coffees and superior products that have been made later will be randomized and given the code description above. For the brewing process all methods are made using the Standard of Procedure (SOP) Cupping with 8,25 gram coffee sample weight, $150 \mathrm{ml}$ water volume, $93^{\circ} \mathrm{C}$ temperature and do not use sugar. For the results of testing the level of preference for these 5 products can be seen below:

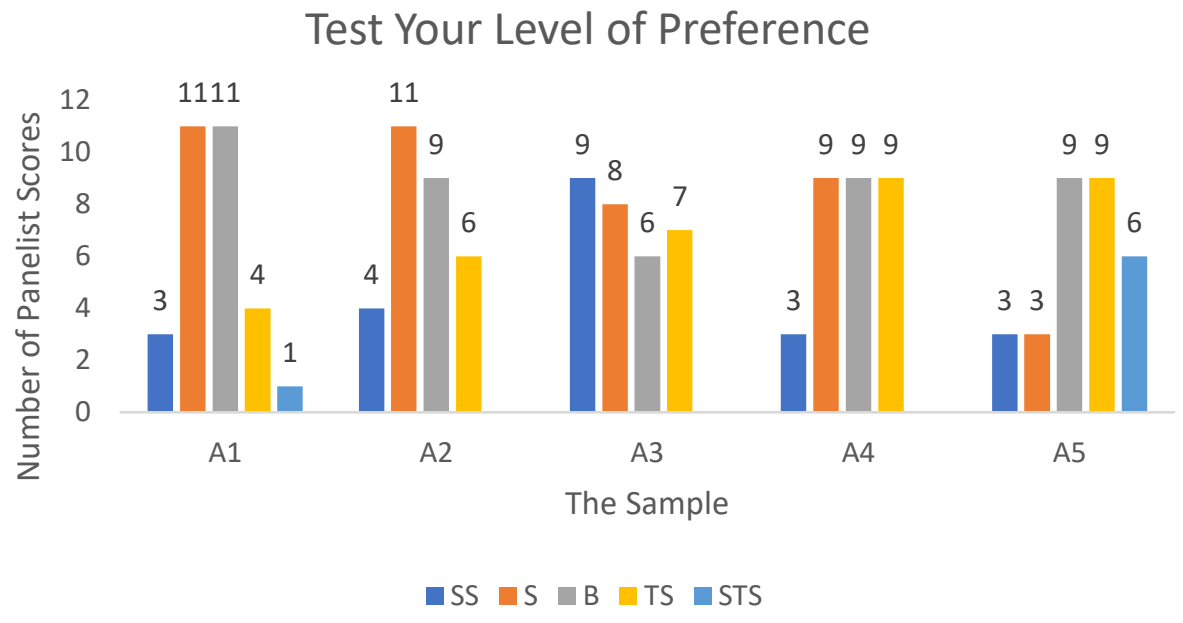

Fig. 3. Test Your Level of Preference.

The graph shows that for A3 coffee products the panelists liked the most with a total of 17 people (Very Like + Likes), whereas for A5 coffee the panelists disliked a total of 15 people (Disliked + Very Disliked). The reason panelists like A3 coffee is because it has a very fragrant aroma, has its own uniqueness because there is a sour taste, bitter taste is almost absent, feels soft in the mouth, coffee is not heavy, the color is bright brown like tea and the taste also fits on the tongue. While A5 is not preferred because it tastes a little bland, too bitter and not suitable on the tongue.

The following criteria interpret the score based on likert scale processing intervals:

- Figures 0\% - 19,99\% (Very Dislike)

- Figures 20\% - 39,99\% (Dislikes)

- Figures 40\% - 59,99\% (Normal) 
- Figures $60 \%$ - 79,99\% (Likes)

- Figures $80 \%$ - 100\% (Really Like)

The following is an interval score table for 5 coffee product samples:

Table 1. Interval scores of 5 coffee product samples.

\begin{tabular}{cc} 
Sample & Interval Score \\
\hline A1 & 67,33 \\
\hline A2 & 68,66 \\
\hline A3 & 72,66 \\
\hline A4 & 64 \\
\hline A5 & 52
\end{tabular}

For interval scores from 5 samples of this coffee product it can be concluded that, for samples A1, A2, A3 and A4 enter the Like category because the interval scores are between $60 \%-79.99 \%$, while for the A5 samples enter the Ordinary category because the interval scores between $40 \%-59.99 \%$. Although A3 is the most preferred by panelists, the difference in score is not too significant. And also can not say A3 coffee is better than other coffee, because consumer tastes vary. All products have their own market.

\section{Conclusion}

So the conclusion that can be drawn is that Bengkulu Robusta coffee has the potential to become a superior product. Coffee products that can be superior are coffee powder with a dry processing, medium roasting and fine milling. The production process is very easy for farmers to apply and the results of the test of the preferred level of superior coffee powder products which are most favored by panelists are 17 people (sample A3).

\section{Suggestion}

Suggestions that can be given are looking for coffee experts who really understand very well about what we want to ask, because interviewees' mistakes can result in us less exploring and getting the information needed. And also for the panelists to test the level of preference to really look for panelists who drink coffee without sugar, because if dismiss the target it can cause our data to be confused. 


\section{References}

[1] [Ditjenbun] Direktorat Jenderal Perkebunan. 2016. Statistik Perkebunan Indonesia Komoditas Kopi 2015 - 2017. Direktorat Jenderal Perkebunan - Kementrian Pertanian. Jakarta.

[2] [BPS] Badan Pusat Statistik. 2017. Statistik Kopi Indonesia 2017. Badan Pusat Statistik. Jakarta.

[3] [MPIG] Masyarakat Perlindungan Indikasi Geografis. 2018. Berita Resmi Indikasi Geografis Seri A. Direktorat Merek dan Indikasi Geografis, Direktorat Jenderal Kekayaan Intelektual, Kementrian Hukum dan Hak Asasi Manusia Republik Indonesia. Jakarta.

[4] Hulupi R. 2012. Prospek Klon - Klon Lokal Kopi Robusta Asal Bengkulu. Pusat Penelitian Kopi dan Kakao Indonesia. Jember.

[5] Randriani E, Dani, Handi S, Syafaruddin. 2016. Ekspresi fenotipik klon kopi Robusta "Sidodadi" pada tiga ketinggian tempat. J TIDP 3(3):151-158.

[6] [MP2IG-KRRL] Masyarakat Penggiat Perlindungan Indikasi Geografis Kopi Robusta Kabupaten Rejang Lebong. 2019. Berita Resmi Indikasi Geografis Seri A. Direktorat Merek dan Indikasi Geografis, Direktorat Jenderal Kekayaan Intelektual, Kementrian Hukum dan Hak Asasi Manusia Republik Indonesia. Jakarta.

[7] [GAEKI] Gabungan Eksportir Kopi Indonesia. 2020. Areal dan Produksi. http://gaeki.or.id/arealdan-produksi/. diakses 26 Februari 2020.

[8] Sugiarti S. 2010. Analisis Pemasaran Kopi di Kecamatan Bermani Ulu Raya Kabupaten Rejang Lebong. J. Agrisep 9(2): 130-136.

[9] Listyati D, Bedy S, Abdul MH, Enny R. 2017. Analisis Usaha Tani dan Rantai Tata Niaga Kopi Robusta di Bengkulu. J. TIDP 4(3): 145-154.

[10] [Kemenperin] Kementrian Perindustrian. 2012. Buku Petunjuk Teknis Penilaian, Klasifikasi dan Pembinaan Produk OVOP. Jakarta : Direktorat Jenderal Industri Kecil dan Menengah.

[11] Triharini M, Dwinita L, R. Susanto. 2014. Pendekatan One Village One Product (OVOP) untuk Mengembangkan Potensi Kerajinan Daerah Studi Kasus: Kerajinan Gerabah di Kecamatan Plered, Kabupaten Purwakarta. J Vis. Art \& Des 6(1): 29-42.

[12] Likert RA. 1932. Technique for the measurement of attitudes. Archives of Psychology, $140 \mathrm{pp:} \mathrm{1-}$ 55.

[13] Rinjani S, Enceng S. 2018. Homogenisasi Susu Beras Menggunakan Metode Pasteurisasi. Industrial Research Workshop and National Seminar. Subang: Politeknik Negeri Subang.

[14] Ridwansyah. 2003. Pengolahan Kopi. Digitized by USU digital library. Universitas Sumatera Utara (USU).

[15] Randriani E, Edi W. 2015. Stabilitas Hasil Tiga Klon Kopi Robusta Bengkulu Sebagai Klon Unggul Lokal. J. TIDP 2(3): 159-168.

[16] KumparanNEWS. 2017. 4 Fakta Kopi Bengkulu Yang Belum Diketahui Banyak Orang https://kumparan.com/kumparannews/4-fakta-kopi-bengkulu-yang-belum-diketahui-banyak-orang.

[17] [Depperin] Departemen Perindustrian. 2009. Roadmap Industri Pengolahan Kopi. Direktorat Jenderal Industri Agro dan Kimia. Jakarta. 


\section{Appendix}

Appendix 1. Coffee Industry Tree.

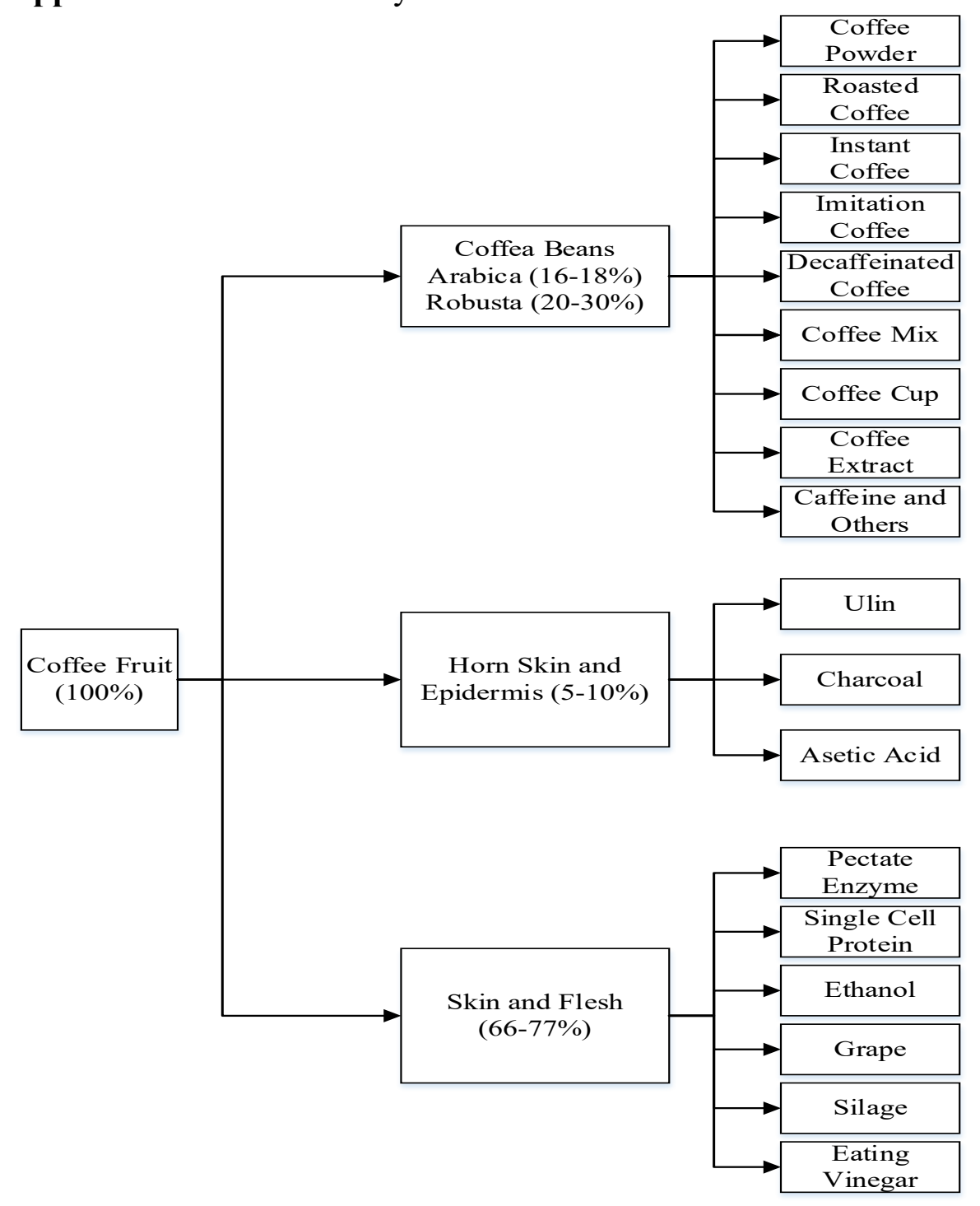

[17] 
Appendix 2. Questionnaire.

\section{Selection of superior products}

1. In your opinion, what coffee product can be a superior product?

2. Why did you choose this superior product?

3. What suggestions can you give about this superior product in the future? Like what

\section{Survey of 30 consumers}

4. Do you prefer a coffee variant in the form of roasted coffee beans or ground coffee? Give your reasons why choose this

\section{Selection of superior product processes}

5. The processing of coffee cherries into coffee beans is generally carried out in two ways, namely the dry method and the wet method. Which way do you prefer? why did you choose this method

6. Furthermore, the process of processing coffee beans into roasted coffee through a choice of roasting processes including light, medium and dark. which roasting process do you prefer? why did you choose that process

7. Furthermore, the process of processing roasted coffee into ground coffee through a choice of grinding processes including: coarse, medium and fine. which milling process you prefer? why did you choose that process 